\title{
Promoting healthy eating habits through awareness campaigns in Poland
}

\author{
Agnieszka Białek-Dratwa ${ }^{1}$, Mateusz Grajek ${ }^{2}$, Łukasz Mencner ${ }^{3}$, Elżbieta Grochowska-Niedworok ${ }^{1}$ \\ 'Department of Dietetics, Chair of Human Nutrition, Medical University of Silesia, School of Public Health, Katowice, \\ Poland \\ ${ }^{2}$ Department of Dietetics, Chair of Technology and Food Quality Evaluation, Medical University of Silesia, School of Public \\ Health, Katowice, Poland \\ ${ }^{3} \mathrm{PhD}$ student, Medical University of Silesia, Katowice, Poland
}

\begin{abstract}
Introduction: The aim of this study was to assess the knowledge of young people about social campaigns related to food and nutrition using as an example the campaigns 'I know what I choose', 'The labeling of food products with GDA' and 'Cool kids do not eat junk food'.
\end{abstract}

Material and methods: The survey was conducted in a group of elementary school students, junior high, and high school students. The final analysis of the survey enrolled 463 people whose questionnaires were completed correctly and returned. Schools participating in the study were randomized from all types of schools.

Results: $63.9 \%$ of respondents demonstrated knowledge of the logo used in the campaign, 'I know what I choose. The respondents were asked about a list of foods which had the information of the Guideline Daily Amounts (GDA). $72.0 \%$ of students, $42.1 \%$ of middle school students, $41.9 \%$ of high school students and $29.4 \%$ of primary school children were able to identify the product with GDA.

Conclusions: Among the respondents, the detailed knowledge of each campaign was not satisfactory. The campaigns 'Cool kids do not eat junk food' and 'I know what I choose' were among the most well-known in the group of pupils in primary school and students. The GDA campaign was the best known in the group of students, but the ability to use the GDA label properly was low. In the study group, body weight did not significantly affect the level of knowledge about social campaigns. However, it was observed that the campaign 'I know what I choose' is better known by persons of normal weight than among people who are overweight or obese.

Key words: social campaigns, diet, children, nutrition education, obesity.

\section{Introduction}

In Poland, there are many social campaigns that involve food and nutrition. Their aim is to promote healthy eating habits in society. Among the campaigns are those that seek to prevent diseases, introduce change in health-promoting lifestyle, including in the daily diet foods favorably affecting health, and social problem awareness raising. Advertising is increasingly targeted at younger audiences, and marketing activities can be observed in educational institutions. In recent years, the following programs concerning individual health promoting eating habits in different age groups have been conducted: 'I know what I choose', 'Fish affects everything, 'The labeling of food products with GDA', and 'Cool kids don't eat junk food'.

\section{I know what I choose}

The 'I know what I choose' campaign is a global initiative designed to help people choose healthy products. It was created to support the World Health Organization (WHO) in its efforts to reduce the growing problem of overweight, obesity and other diet-related diseases. 'I know what I choose' is the Polish part of an educational campaign and information on food labeling 'Choices'. This program was established in 2006. Its purpose was to facilitate consumer choices of food products so that

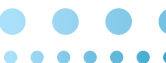

$\bullet \bullet$ 
Promoting healthy eating habits through awareness campaigns in Poland
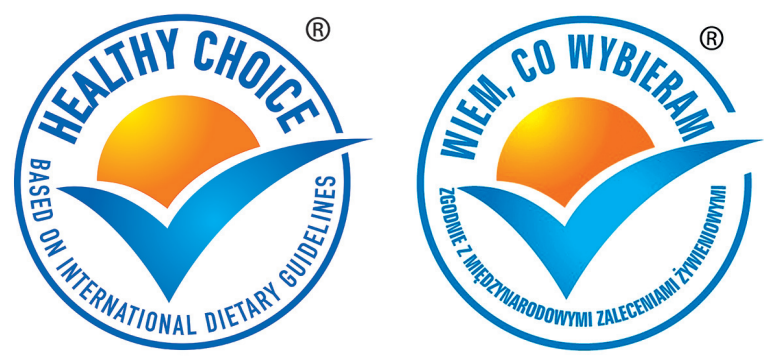

Figure 1. Logo of the program 'I know what I choose' Choices - international and Polish version [4,5]

they could arrange a balanced diet. The founders believe that the food industry should improve the composition of their products leading to a balanced daily diet. The authors of the campaign indicate that the program itself is a response to consumer demand and changes in public awareness about the food industry. This program addresses the whole society - consumers, regardless of age, gender, social status and education.

The logo has been designed for consumers so that they can easily find the product of the program. Foods in the program must include a certain amount of four nutrients based on international dietary recommendations. These nutrients are saturated fats, trans fatty acids, sugar and salt [1-5].

In Poland, the initiators of the campaign were the leading food manufacturers. The campaign included television advertising, the Internet, billboards (Fig. 1), press releases and information on the campaign website http://www.wiemcowybieram.pl. The logo that has been used in the Polish edition currently appears on more than 100 food products. Polish educational materials and information published on the website of the campaign refer to the dietary recommendations based on the Harvard Healthy Nutrition Pyramid in 2005. The material consists of 10 tips on how to live healthily, which directly relates to dietary guidelines proposed by the Harvard School of Public Health and the Polish Institute of Food and Nutrition (IZZ) $[1,2,5]$.

\section{The labeling of food products with GDA}

Product branding is one of the elements of nutrition education. The labeling of food products should contain clear and understandable information on nutrition.

GDA (Guideline Daily Amount) is the information provided on food products. This modern method of labeling foods is determined in approximate percentage levels of consumption of various nutrients found in certain foods. Labeling of food products is the caloric value, fat, saturated fat, carbohydrates, total sugars, fiber, protein, salt and sodium [6-11].

'The GDA labeling of food products' has been developed in accordance with the Polish and EU law for the proper labeling of nutritional value. This marking comprises:

- marking the front of the package - determines the amount of calories, which is located in one portion and the \% of GDA presented graphically,

- marking of the back of the package - gives minimum information that must be included on the package: energy - calories, protein, fat and carbohydrates.

In Poland, the system was designed and implemented in September 2007. The program aims to introduce labeling of nutritional value of food that will be understandable and accessible to the public, the same for all foods and beverages based on current scientific evidence, and will help to reduce the development of overweight and obesity $[8,10,11]$.

\section{Cool kids do not eat junk food}

The campaign 'Cool kids do not eat junk food' was conducted in September and October 2009 in several cities in Silesia (Poland). The action was financed from the budget of the Marshal Office of the Silesian Province. The objective of the program was to encourage children to give up eating fast food, sweets, crisps, fries, and pizza and encourage the change to healthy eating habits. Doctors and nutritionists were involved in its implementation. Primary school pupils were given badges with body mass index (BMI) indicators, and overweight children had prepared a special diet. Within this campaign stickers on bins and billboards with the phrase 'Cool kids do not eat junk food' [12] were used.

\section{Objectives}

The aim of this study was to assess the knowledge of young people about social campaigns related to food and nutrition based on the example of the campaigns 'I know what I choose,' 'The labeling of food products with GDA' and 'Cool kids do not eat junk food'. The study took into account the weight of respondents and rated the relationship of body weight to the level of knowledge about social campaigns on food and nutrition.

\section{Material and methods}

The survey consisted of elementary school students, junior high students, high school students, and university students living in two cities of Upper Silesia - Katowice and Siemianowice Sląskie. The study included 500 people. The final analysis of the survey enrolled 463 people whose questionnaires were completed correctly and returned. Schools participating in the study were ran- 


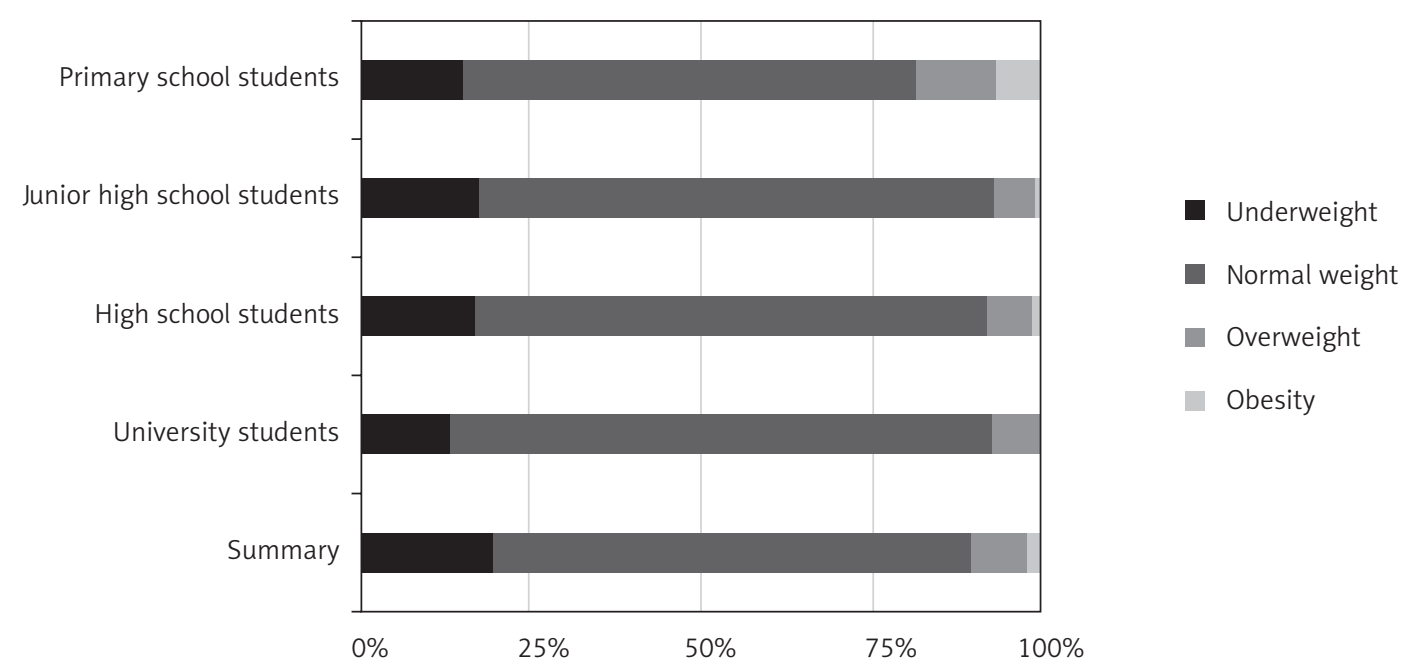

Figure 2. Characteristics of the study group according to body weight

domized from all types of schools: two primary schools, two junior high schools, and two high schools. In each of the randomly selected schools there were randomly selected three classes, where students took part in the study. In primary schools, students in grades 1-4 did not participate in the study because they do not have the skills to fill in the questionnaire correctly. Students were selected by randomized 6 groups of all students from the University of Silesia. We excluded paramedical, biological and sociological students, because their knowledge may interfere with the test results. The survey was conducted from November 2013 to February 2014. The study was conducted on the basis of the authors' questionnaire. The survey respondents were 275 girls and 188 boys, aged 11-27 years. The average age in the whole group was $16.1 \pm 3.4$ years. For the statistical analysis a $\chi^{2}$ test was used. The statistical significance level was $p \leq 0.05$. The respondents were asked about their weight and height. The obtained data were used to calculate the BMI. For the analysis of body weight we used centile charts of BMI for Polish boys and girls (2010). In accordance with the recommendations of the Polish Children's Health Center underweight was considered to be present among children when the BMI was within the range 0 to 10 percentiles of BMI, standard weight within 10-85 percentiles, overweight 85-95, and obesity 95-100 [13] (Fig. 2).

\section{Results}

The study group included 463 students: 119 elementary school students (25.7\% of the study group), 126 junior high school students (27.2\%), 136 high school students $(29.4 \%)$ and 82 university students (17.7\%). Due to the structure of Polish society, the group of students was less numerous than the other groups.
Among primary school children, $66.4 \%$ of respondents were characterized by normal weight, $15.1 \%$ were underweight, $11.8 \%$ were overweight and $6.7 \%$ suffered from obesity. In the group of junior high school students $75 \%$ were of normal weight, $18 \%$ underweight, $6 \%$ overweight and $1 \%$ were obese. In the group of high school students $75 \%$ were normal weight, $17 \%$ were underweight, $7 \%$ of them were overweight and $1 \%$ suffered from obesity. Among students 79\% were normal weight, $14 \%$ were underweight and $7 \%$ was diagnosed with overweight and obesity.

$63.9 \%$ of respondents demonstrated their knowledge of the logo used in the campaign 'I know what I choose'. The number accounted for $68.1 \%$ of elementary school students, $66.7 \%$ of junior high school students, $64.7 \%$ of high school students and $52.4 \%$ of students. Among those who did not know the logo of the campaign were: $18.5 \%$ of the youngest participants in the study, $23.0 \%$ of junior high school students, $15.4 \%$ of high school students and $20.7 \%$ of students. Statistical analysis showed statistically significant differences between the groups (Fig. 3 and 4).

In the group of underweight respondents, knowledge of the logo was declared by $0.1 \%$ of respondents, among those with normal weight by $63.3 \%$, by $55.6 \%$ of overweight and by $60.0 \%$ of obese. Ignorance of the logo was declared by $17.2 \%$ of underweight, $18.5 \%$ of normal weight, $25.0 \%$ of overweight and $10 \%$ of obese.

The respondents were asked the following question: what does the campaign logo, which is located on the food product, mean? The correct answer is: the product is in conformity with international nutritional recommendations - this answer was marked by $35.6 \%$ of all respondents, including $19.3 \%$ of elementary school students, $40.5 \%$ of junior high school students, $38.2 \%$ of high school students and $47.6 \%$ of university students. 


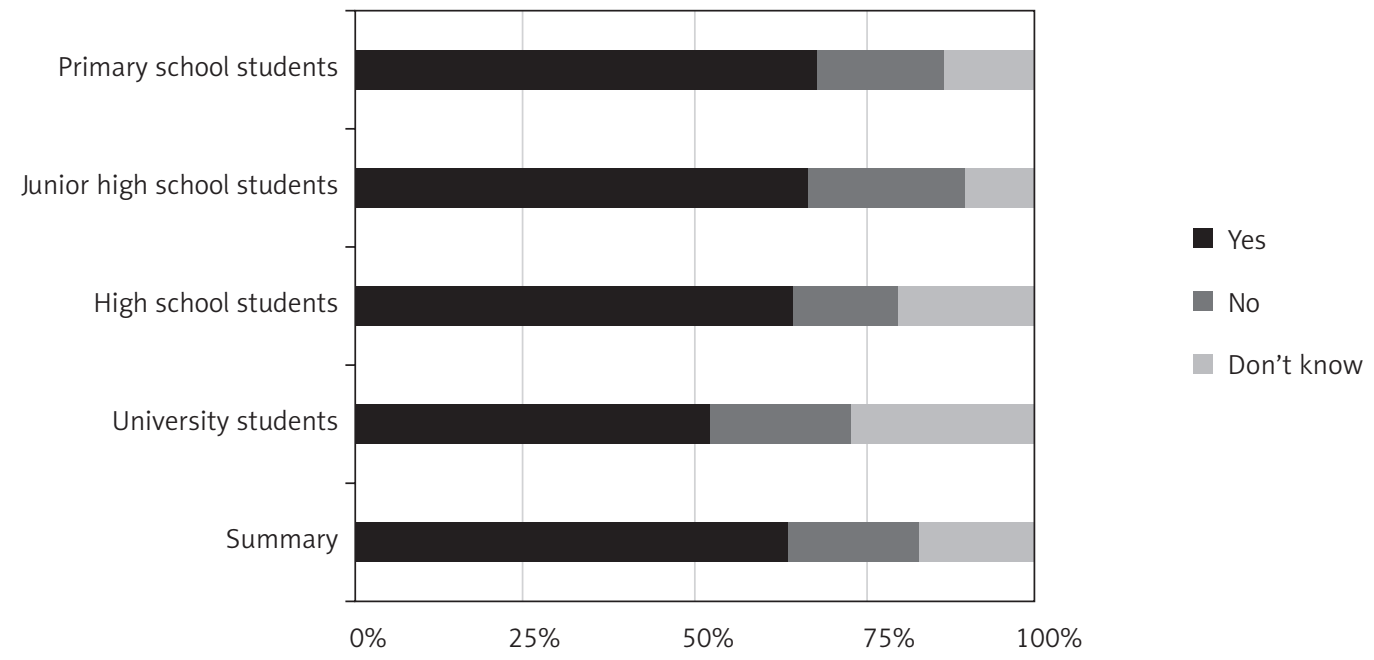

Figure 3. Knowledge of the campaign logo 'I know what I choose'

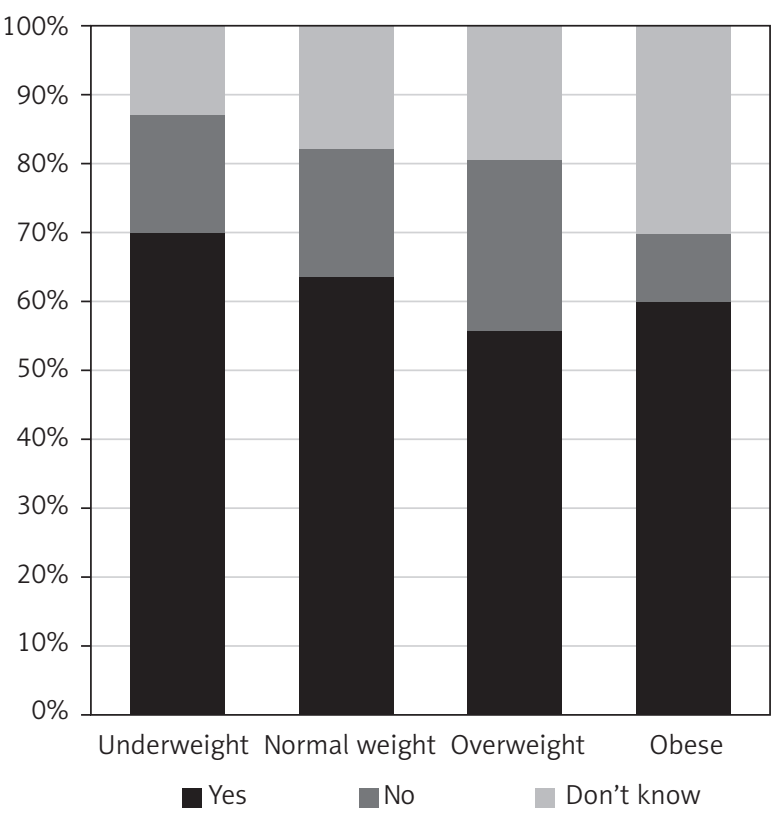

Figure 4. Knowledge of campaign logo 'I know what I choose' depending on the weight of the respondents

Statistical analysis showed statistically significant differences between the groups.

$26.1 \%$ of elementary school students, $54.0 \%$ of junior high school students, $50.0 \%$ of high school students and $84.1 \%$ of students responded 'yes' to the question 'Have you ever seen the GDA labeling of food products?' However, $43.7 \%$ of elementary school students, $30.2 \%$ of junior high school students, $30.1 \%$ of high school students and $7.3 \%$ of students had not seen the GDA labeling of food products. Differences between the groups were statistically significant (Fig. 5).
Respondents were asked if they knew the concept of GDA. $55.2 \%$ of underweight, $48.1 \%$ of those with normal weight, $44.4 \%$ of overweight and $80.0 \%$ of obese answered that they did not know the GDA.

The respondents most often had seen the GDA labeling on food products - 141 people. Eighty of them had read the information or seen it in the media such as TV and the Internet. 191 respondents had never seen the data of the GDA. Differences between the groups were statistically significant.

The respondents had to indicate whether the GDA is the same for everyone, regardless of age and gender. In the whole group, $14.3 \%$ of people said 'yes', $57.2 \%$ replied 'no' and 28.5\% answered 'I don't know'. Among elementary school students $25.2 \%$ answered 'yes', $28.6 \%$ 'no,' and $46.2 \%$ replied 'I don't know'. In the group of junior high school students, $13.5 \%$ stated that GDA is the same for everyone, $57.9 \%$ answered 'no', and $28.6 \%$ said 'I don't know' $11.8 \%$ of high school students and $3.7 \%$ of university students felt that the GDA is the same for everyone. $65.4 \%$ of high school students and $84.1 \%$ of university students claimed that the GDA was differentiated by age and sex. Statistical analysis showed that the differences between the groups are statistically significant.

The same question was analyzed in terms of body weight of subjects. $10.3 \%$ of underweight, $15.6 \%$ of normal weight, $5.6 \%$ of overweight and $50 \%$ of obese felt that for all the GDA is the same. $51.7 \%$ of underweight, $62.2 \%$ of normal weight, $52.8 \%$ of overweight and $20 \%$ of obese felt that GDA is different depending on age and gender. $37.9 \%$ of underweight, $25.3 \%$ of normal weight, $41.7 \%$ of overweight and $30 \%$ of obese did not know whether GDA is the same for all, or whether it is different depending on gender and age. 


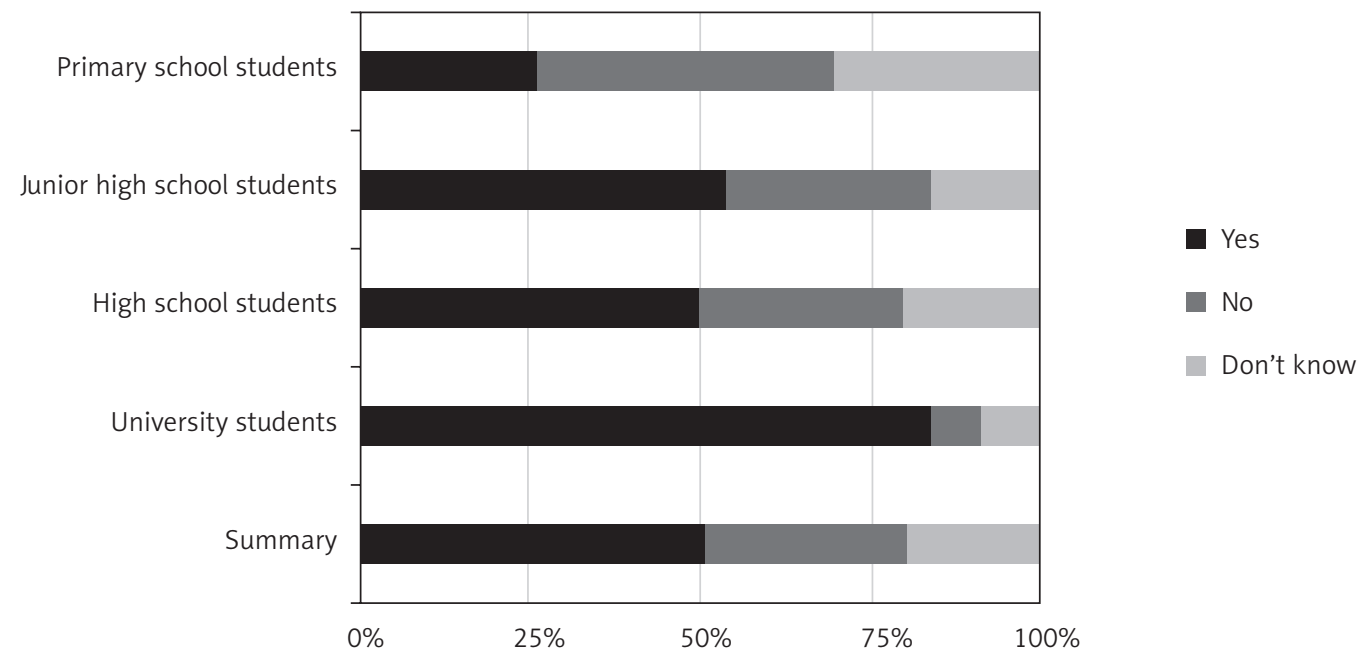

Figure 5. Survey respondents' replies to the question: Have you ever seen the GDA labeling of food products?

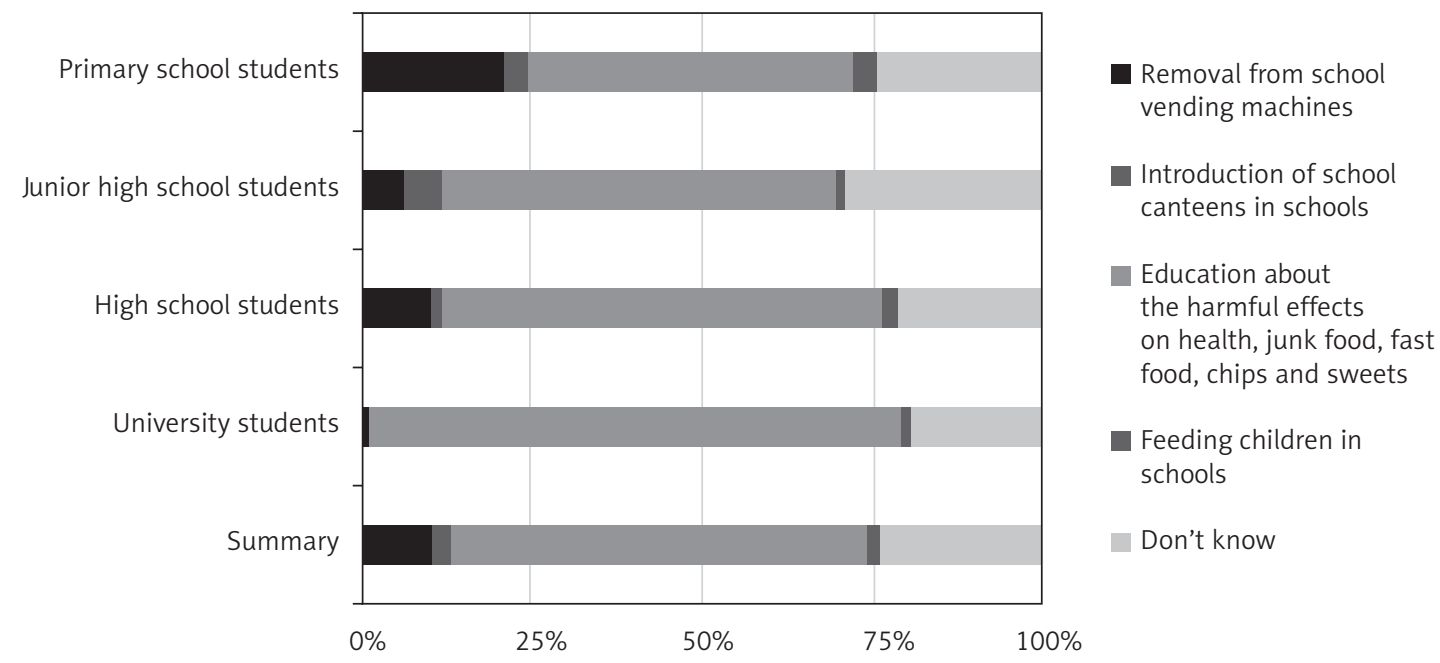

Figure 6. What is the social campaign 'Cool kids do not eat junk food' about? - knowledge about the campaign in the respondent groups

Respondents were asked about the use of GDA signs when they buy food products. $11.8 \%$ of elementary school students, $16.7 \%$ of junior high school students, $13.2 \%$ of high school students and $17.1 \%$ of university students use GDA when they make consumer choices.

Figure 6 shows the knowledge about the campaign 'Cool kids do not eat junk food'. The correct answer to the question 'What is the most important thing in the campaign $<<$ Cool kids do not eat junk food $>>$ ' was 'The education campaign concerns harmful effects on health, eating fast food and crisps and sweets. The correct answer was given by $60.9 \%$ of respondents, including $47.9 \%$ of elementary school students, $57.9 \%$ of junior high school students, $64.7 \%$ of high school students and $78.0 \%$ of university students. $24.0 \%$ of respondents could not identify any response, including $24.4 \%$ of the youngest respondents, $29.4 \%$ of junior high school students, $21.3 \%$ of high school students and $19.5 \%$ of university students. $21.0 \%$ of pupils in primary schools, $6.3 \%$ of junior high school students, $10.3 \%$ of high school students and $1.2 \%$ of university students felt that the program 'Cool kids do not eat junk food' referred to removing soda from school vending machines. The differences in responses between the groups were statistically significant.

\section{Discussion}

In 2009, the Interactive Institute for Market Research (IIBR) conducted a study about the knowledge of the social campaign 'I know what I choose'. $20.1 \%$ of Polish respon- 
Table 1. Where did you see GDA labbeling? - respondents' answer to this question

\begin{tabular}{|c|c|c|c|c|c|c|}
\hline & $\begin{array}{l}\text { Never seen } \\
\text { with GDA }\end{array}$ & On all foods & On some foods & $\begin{array}{c}\text { Read } \\
\text { an information } \\
\text { of GDA }\end{array}$ & $\begin{array}{c}\text { Read/heard } \\
\text { in mass media }\end{array}$ & Different \\
\hline $\begin{array}{l}\text { Primary school } \\
\text { students }\end{array}$ & $38.2 \%$ & $4.2 \%$ & $12.6 \%$ & $2.6 \%$ & $5.8 \%$ & $1.0 \%$ \\
\hline $\begin{array}{l}\text { Junior high } \\
\text { school students }\end{array}$ & $23.6 \%$ & $13.6 \%$ & $18.8 \%$ & $6.3 \%$ & $10.5 \%$ & $3.1 \%$ \\
\hline $\begin{array}{l}\text { High school } \\
\text { students }\end{array}$ & $33.0 \%$ & $9.4 \%$ & $19.9 \%$ & $2.6 \%$ & $13.6 \%$ & $1.0 \%$ \\
\hline $\begin{array}{l}\text { University } \\
\text { students }\end{array}$ & $5.2 \%$ & $11.0 \%$ & $22.5 \%$ & $2.6 \%$ & $12.0 \%$ & $3.7 \%$ \\
\hline
\end{tabular}

Table 2. Do you think the GDA is the same for everyone regardless of age and gender?

\begin{tabular}{|l|c|c|c|}
\hline & Yes & No & Don’t know \\
\hline $\begin{array}{l}\text { Primary school } \\
\text { students }\end{array}$ & $25.2 \%$ & $28.6 \%$ & $46.2 \%$ \\
\hline $\begin{array}{l}\text { Junior high } \\
\text { school students }\end{array}$ & $13.5 \%$ & $57.9 \%$ & $28.6 \%$ \\
\hline $\begin{array}{l}\text { High school } \\
\text { students }\end{array}$ & $11.8 \%$ & $65.4 \%$ & $22.8 \%$ \\
\hline $\begin{array}{l}\text { University } \\
\text { students }\end{array}$ & $3.7 \%$ & $84.1 \%$ & $12.2 \%$ \\
\hline Summary & $14.3 \%$ & $57.2 \%$ & $28.5 \%$ \\
\hline
\end{tabular}

dents knew the campaign logo, including $86.5 \%$ of them associating it with food. $70 \%$ of respondents said they would like to purchase products with this logo. The campaign, 'I know what I choose' contributed to the increase in sales of food products marked with the logo. Unilever has observed the growth of sales of these products by 7 percentage points [14]. In a study conducted in Denmark respondents were asked about the benefits resulting from the consumption of products labeled with 'Choices'. $63 \%, 40 \%, 36 \%$ and $23 \%$ of respondents felt that the intake of trans fatty acids, saturated fat, sugar and sodium, respectively, was reduced [15].

In the report, the European Consumers' Perception of Foodstuffs Labelling, 87\% of Poles thought that nutrition information on the label was necessary. Nearly $50 \%$ of Poles examined the labels about portion sizes and fat content of the food product. The energy value of food products is checked by $35 \%$ of respondents. The same report showed that the majority of respondents do not read nutrition information on products. This study proved that there is a lack of sufficient awareness among Poles about nutrition information on labels affixed to food, and that people lack the ability to translate this information into nutritional benefits used in the daily diet. The source of the knowledge of Poles about nutrition, according to the report European Consumers' Perception of Foodstuffs Labelling, was the information appearing on television, magazines and on the packaging of food products [16,17]. The regulation of the Minister of Health on food labeling nutritional value is applied to the nutritional labeling requirement and the content of protein, carbohydrates and fats in food for caterers and consumers [18].

\section{Conclusions}

1. Among the respondents, detailed knowledge of each campaign was not satisfactory.

2. The campaigns 'Cool kids do not eat junk food' and 'I know what I choose' were among the most wellknown in the group of pupils in primary school and students.

3. The GDA campaign was the best known in the group of students, but the ability to use the GDA label properly was low.

4. In the study group, body weight did not significantly affect the level of knowledge about social campaigns. However, it was found that the campaign 'I know what I choose' is better known by persons of normal weight than among people who are overweight or obese.

\section{Disclosure}

Authors report no conflict of interest.

\section{References}

1. Polish website of 'Choices': http://www.wiemcowybieram.pl/ files/files/20100801_Harvard_Business_Review_Dodatek.pdf; available at the date of November $24^{\text {th }}, 2015$.

2. Polish website of 'Choices': http://www.wiemcowybieram.pl/ kryteria_programu.html; available at the date of November $24^{\text {th }}$, 2015.

3. Zientek-Varga J. Kupowanie klienta znakami. Fresh \& Cool Market 2008; 11: 26-28. 
4. Website of 'Healthy Choices': http://www.choicesprogramme. org/en; available at the date of November $24^{\text {th }}, 2015$.

5. Polish website of 'Choices': http://wiemcowybieram.pl; available at the date of November $24^{\text {th }}, 2015$.

6. Website of "Healthy Choices": http://www.choicesprogramme. org/public/useful-documents/labelling_report_en.pdf; available at the date of September $8^{\text {th }}, 2014$.

7. Website of "The What's inside guide": http://www.gdalabel. $\mathrm{com} /$; available at the date of November 24th 2015.

8. Website of Polish Federation of Food Industry, Website of The labeling of food products GDA: www.gdainfo.pl/; available at the date of November $24^{\text {th }}, 2015$.

9. Website of Polish Federation of Food Industry: www.pfpz.pl/ index/?id=0b105cf1504c4e241fcc6d519ea962fb; available at the date of November 24 ${ }^{\text {th }}, 2015$.

10. Website of Polish Federation of Food Industry: Dobrowolny program znakowania wartością odżywczą. GDA, Warszawa 2007; www.pfpz.pl/files/?id_plik=858; available at the date of November $24^{\text {th }}, 2015$

11. Kozłowska D. Dobrowolny System Znakowania Wartością Odżywczą GDA - Zasady. Warszawa 2008.

12. Website of the Foundation for Social Communication: Cool kids don't eat junk food. 09.2009; http://www.kampaniespoleczne.pl/ kampanie,940,fajne_dzieci_nie_jedza_smieci; available at the date of November 24 $4^{\text {th }}, 2015$.

13. Kutaga Z, Litwin M, Tkaczyk M. Polish 2010 growth references for school-aged children and adolescents. Eur J Pediatr 2011; 170 599-609.

14. Tomczak W. Konsument dobrze poinformowany. Harvard Business Review 2010; http://www.wiemcowybieram.pl/files/files/ 20100801_Harvard_Business_Review_Dodatek.pdf; available at the date of November $24^{\text {th }}, 2015$.

15. Roodenburg AJ, Temme EH, Howell Davies O, et al. Potential impact of the Choices Programme on nutrient intakes in the Dutch population. Nutrition Bulletin, 2009.

16. The labeling of food products GDA. Ogólnopolski Dobrowolny Program Znakowania Wartością Odżywczą GDA. Państwowa Inspekcja Sanitarna, 2007.

17. Report on European Consumers' Perception of Foodstuffs Labelling. BEUC, 2005.

18. Regulation of the Minister of Health on 25 July 2007. Concerning marking alive-ness nutritional value. Rozporządzenie Ministra Zdrowia z dnia 25 lipca 2007 r. w sprawie znakowania żywności wartością odżywczą. Dziennik Ustaw z 31 lipca 2007 Nr 137, poz. 967. 